\title{
Investigating the presumed causal links between drought and dzud in Mongolia
}

\author{
Troy Sternberg ${ }^{1}$
}

Received: 26 March 2016/Accepted: 28 March 2017/Published online: 21 April 2017

(C) The Author(s) 2017. This article is an open access publication

\begin{abstract}
Extreme weather events present environmental and social challenges across the Eurasian steppe. In Mongolia much attention is given to drought and dzud (severe winter conditions) impact on rural livelihoods, landscapes and governance. A link between the two events, fostered by international and state agencies, speculates that drought leads to dzud; this has become the widely accepted doctrine. However, the relationship between the two events is assumed rather than analysed. Whilst there may be natural links between climate events, causality is more difficult to establish yet often claimed post-event. This paper stresses Mongolia's destructive dzuds of 1999-2001 and 2009-2010 in examining drought frequency before dzud events. Findings question the hazard connection as just 3 of 32 examined dzud events were preceded by drought. Investigation did not document a relationship between the disasters; linkages between extreme events were implied rather than established. The human role in disaster also needs to be assessed as preparation, and response are key factors for mitigation. Study results identified a lack of causality between the disasters, suggesting more assiduous investigation of hazards is needed in Mongolia. This can clarify causal factors, identify risk and improve disaster mitigation strategies in Mongolia.
\end{abstract}

Keywords Drought $\cdot$ Dzud $\cdot$ Causality $\cdot$ Mongolia $\cdot$ Natural hazards

\section{Introduction}

Natural hazards disrupt physical processes, disrupt social systems and dislocate livelihoods and communities. Identifying and understanding endemic natural hazards is essential to reducing risk, mitigating disasters and strengthening adaptation to extreme climate events.

Troy Sternberg

troy.sternberg@geog.ox.ac.uk

1 University of Oxford, Oxford, UK 
This is critical in societies where residents are directly dependent on the environment for their livelihoods. Across the Eurasian steppe pastoralism exemplifies the exposure and vulnerability of livestock, households and governance to extreme climate conditions. For instance, in Mongolia, drought and dzud (severe winter conditions) create the greatest threats to animal mortality and herder well-being (IPCC 2012; Fernandez-Gimenez et al. 2012; Shinoda 2012). The destructive national impact of dzud events reached crisis proportions in 1999-2001; the 2009-2010 disaster killed $\sim 25 \%$ of the national herd, led to significant displacement as $3 \%$ of the population lost livelihoods and reduced GDP by $-4.4 \%$ (Batima et al. 2005; Sternberg 2010) whilst 1.1 million animals died in the 2015-2016 event (UN 2016). Numerous academic, government, international NGO publications and news reports highlight how concurrent or sequential natural hazards threaten society by stressing causality between drought and dzud that creates significant disasters (IPCC 2012; UNOCHA 2010).

A presumed connection between drought and dzud has become the standard narrative in research, policy and mitigation strategies. Whilst there has been notable research on dzud impacts (Tachiiri et al. 2008; Middleton et al. 2015; Rao et al. 2015), the drought-dzud link is often inferred rather than investigated. As a cold, dry environment limited rainfall and severe winter conditions (temperatures to $-40{ }^{\circ} \mathrm{C}$ ) are threats to pastoral livelihoods. The Government of Mongolia (2001) stressed the impact of a prolonged summer 2000 drought on the 2001 dzud, Fernandez-Gimenez et al. (2012) identified several droughtdzud events and Shinoda (2012) found the two events associated. The World Bank (2010), FAO (2010) and general media, such as the New York Times (2016), identified summer drought as antecedent to severe dzuds.

Dzuds, particularly the 2010 event, are regarded as the country's worst natural disaster (Sternberg 2010); their immediacy consumes attention, aid and resources. Direct and antecedent events are acknowledged yet receive limited examination or integration into dzud strategies. Indeed, what constitutes a dzud is debated and reflects the lack of clarity. Table 1 presents dzud definitions, whilst Table 2 reflects diverse perceptions of dzud. Herders' traditional ecological knowledge contributes local perspectives on dzud, from 'drought causes dzud' (Fernandez-Gimenez et al. 2012) to celestial signals (position of stars, shape of the moon), animal behaviour (marmots sealing burrows, sheep leave mountains early in autumn, livestock fight in autumn) and plant signs (yellowing of leaves from top of tree) (Middleton et al. 2015). The dominant focus is on natural disaster and meteorological events though social and livestock parameters are also considered. This reflects how dzuds and their contributory factors can be perceived differently. Thus perspectives on causality, correlation or circumstance vary and are often not examined. When

Table 1 Dzud definition

White dzud deep snow with density $>0.20 \mathrm{~g} / \mathrm{cm}^{3}$

Black $d z$ ud lack of snow, freezing temperatures $5.0{ }^{\circ} \mathrm{C}$ below average

Iron $d z u d$ snow cover melts and refreezes to form an impenetrable ice cover that prevents livestock from foraging

Cold $d z u d$ severe cold with temperatures lower than monthly mean for several days

Hoof dzud extreme dry weather leading to depletion of grass due to heavy grazing and trampling Storm dzud heavy snow and high winds

Combined dzud multiple dzud conditions occurring simultaneously

FAO/Suttie (2006), Middleton et al. (2015), Rao et al. (2015) 
Table 2 Perceptions of dzud, with sources

\begin{tabular}{ll}
\hline Complex, long-lasting natural disaster & IFRC (2016) \\
Extremely harsh winters characterised by heavy snow and low temperature & Miao et al. (2016) \\
Meteorological phenomenon & Mayer (2016) \\
Complex social and ecological phenomenon & Murphy (2011) \\
Incidences of mass livestock mortality & Rao et al. (2015) \\
Unique weather phenomenon & World Bank (2011) \\
\hline
\end{tabular}

the FAO/Suttie (2006) or UN/Mongolian National Emergency Management Agency (2010) report on dzud and link events to drought, the drought is not quantified, a process that repeats throughout dzud studies (Table 2). This is a major research gap and failure in comprehension. The 2010 dzud decimated livestock and livelihoods to catastrophic levels yet work evaluating and distilling cause and effect remains negligible. This paper frames the challenge through concise investigation of drought-dzud interaction to examine potential causality, relation or independence of the two natural disasters.

Themes reflect key policy, planning and donor country perspectives on disaster in Mongolia where agendas, government action and international assistance are based on conventional paradigms of climate-environment-human interactions (see above, World Bank 2011). Thus, for effective disaster mitigation and risk reduction in Mongolia, clear comprehension of natural hazards, causal factors and their interaction is essential for disaster preparation and response.

\section{Disaster in Mongolia}

There is a long, established dzud record in Mongolia with growing literature on several aspects of dzud (IPCC 2012; Shinoda 2012; Fernandez-Gimenez et al. 2012). Dzud is particularly damaging to rural livelihoods and mobile pastoralism that provide income for $30 \%$ of the population. Work by the UN/Mongolian National Emergency Management Agency (2010) identifies extreme events in 1945, 1999-2002 and 2009-2010 (Table 3). The important condition is restricted forage and animal exposure to extreme cold that leads to mortality, particularly in spring after the long winter. Coping strategies include adequate grain and fodder storage, livestock offtake in autumn, otor (long distance movements) and reduced pregnancy rates to improve animal survival in harsh winters. International relief

Table 3 Dzud relation to drought, with sources

Natural disaster-drought followed by heavy snow, low temperatures

Stems from summer droughts

Prolonged summer drought impacts dzud

Consequence of a summer drought and extreme overgrazing leading to insufficient hay for winter grazing

Heavy drought in late summer followed by intense snow storms

Triggered by prolonged drought

Dzud follows drought

\section{UNOCHA (2010)}

Murphy (2011)

Government of Mongolia

IFRC (2016)

World Bank (2011)

FAO (2010)

Herder saying, in FernandezGimenez et al. (2011), p. 14 
Table 4 Historical dzud record established by the Government of Mongolia (UN/National Emergency Management Agency 2010); international agencies (World Bank/Benson C 2011) and academics (FernandezGimenez et al. 2012; Middleton et al. 2015)

\begin{tabular}{lll}
\hline Year & Event & $\begin{array}{l}\text { Livestock mortality } \\
\text { (millions) }\end{array}$ \\
\hline $1944-1945$ & Dzud + Drought & 8.6 \\
$1954-1955$ & & 1 \\
$1956-1957$ & & 1.8 \\
$1967-1968$ & Dzud + Drought & 3.8 \\
$1976-1977$ & Dzud & 4.1 \\
$1986-1987$ & Dzud & 0.8 \\
$1993-1994$ & Dzud & 0.8 \\
$1996-1997$ & Dzud & 0.7 \\
$1999-2002$ & Dzud + Drought & 10.8 \\
$2009-2010$ & Dzud + Drought & 10.3 \\
$2015-2016$ & Dzud + Drought & 1.1
\end{tabular}

efforts offer limited dzud relief; for example, after the 2010 disaster $>\$ 18$ million in aid was promised yet only $\$ 3+$ million was received (World Bank/Benson C 2011). Response to the 2010 dzud highlights both the limited domestic mitigation capacity and the country's dependence on international assistance for dzud relief (Sternberg and Batbuyan 2013).

Climate research highlights drought prevalence in Mongolia. Whilst Pederson et al. (2014) suggest drought in the late twelfth century may have influenced Chinggis Khan's formative years; Bayarjargal et al. (2006), Sternberg et al. (2011) and Nandintsetseg and Shinoda (2013) examined multifaceted drought impacts on environment on society. Little work has explicitly addressed drought/dzud interaction, although Sternberg et al. (2009) disaggregated drought and dzud in Omnogovi Province from 1999 to 2002. Though identified, the theme has not become part of the policy or mitigation discourse. The outcome has been a presumed link between drought and dzud (see Table 4) ascribed to physical factors, whilst concurrently the socio-economic nature of dzud has gained wide recognition (Murphy 2012; Fernandez-Gimenez et al. 2012). As causal factors for dzud become a major concern, clarity is needed on the complex interplay of contributory factors to address detrimental outcomes. This highlights how human action, such as decisions that affect the number of livestock, mobility, use of water sources and intensified herding practices, affects dzud impact. Through examination of historical drought and recorded dzuds, we evaluate the potential link between drought and dzud disasters. The outcome can identify natural relationships, clarify causality, suggest event independence or reflect a more nuanced relation between the two hazards.

\section{Causality}

An understanding of causality is essential to identify possible connections between natural events (e.g. drought and dzud) and attempt to separate biophysical risk from social capacity and response (Cutter et al. 2008). In evaluating forecasting, planning and response the antecedent structures and follow-on consequences are key; causality can be seen as a flow of processes. However, correlation does not prima facie identify a cause-effect relationship but rather indicates an important path of further investigation (Rajsekhar et al. 2015). This is a significant point in evaluating major hazards in Mongolia and reflects the ability of original research to highlight critical associations that may be missed or ignored at first 
glance. This is particularly salient to in a discussion of drought, an event which remains elusive when identifying onset, extent and impact due to its variegated spatio-temporal scale and ensuing effects. As the most widespread hazard affecting the greatest number of people globally, drought is routinely perceived as a common causal and detrimental episode in multiple socio-environmental contexts; research can verify whether the conventional perception is valid at local and regional levels (Rajsekhar et al. 2015; Sternberg et al. 2011).

Relevant to research on two potentially related hazards, Below et al. (2007) stressed how a disaster often represents a cumulative attribution of losses across sectors, including physical and social domains. In Mongolia, this sees drought attributed to climate change and global warming with impacts as diverse as drying of water sources, reduced pasture biomass, lowered animal weight gain and degradation of the steppe landscape. Dzud is ascribed to changing weather patterns, severe cold, shifts in pastoralism, poor policy or lack of preparedness, socio-economic forces, the 'market-economy' and most frequently drought (UN/National Emergency Agency 2010). The challenge of disaster attribution is key to the Mongolian context where policymakers and practitioners seek to assign disaster causality to reduce uncertainty, attribute liability to physical factors that are beyond state control and determine reference conditions which can then be addressed through intervention, new policy and often by international aid or development projects (i.e. World Bank's Sustainable Livelihoods Program, the UN's Strengthening Disaster Mitigation Strategy).

Appropriate identification and attribution of Mongolia's drought and dzud encompasses several factors. As a developing nation limited research capacity, few alternate sources of funding (aid, relief), low to moderate intervention capacity and physical limitations (distance, infrastructure, timeliness, effective delivery mechanisms) combine to frame disaster risk and strategy. If initial presumptions about causal relationships are adequate and established, then policy can build on real-world circumstances as a foundation. A Mongolian example was widespread pasture degradation in 2005 attributed to the tsar-tsai (grasshopper/insect) invasion that focused response on containing the insect population rather than assigning culpability to overgrazing or climate (Hauck et al. 2008). Similar clarity is needed for the dominant hazards that consume attention, focus and resources of the government and herders. For example, pastoralists identify hazard mitigation through mobility, fattening of animals, reserve pastures and reciprocal land use patterns (Fernandez-Gimenez 2000). The questions surrounding drought and dzud make clarity key to system behaviour and livelihood improvement in the country. As several citations show (FAO 2010; Murphy 2011; IFRC (International Federation of the Red Cross) 2016), definitive causative understanding of the country's major disasters has been marginalised in favour of long-standing assumptions. This paper addresses the knowledge gap through investigating cause and attribution between drought and dzud.

\section{Methods}

To investigate the relationship between drought and dzud in Mongolia, diverse geographical sites were chosen. This provides a prima-facie assessment of drought-dzud at a national scale through a focus on four different regions of the country. Sites were selected to represent landscape variability, present distribution in areas identified as vulnerable to dzud and drought and had working meteorology stations (World Bank 2011). The vast 
country, 1.56 million $\mathrm{km}^{2}$, covers several ecotones and much environmental variety. The study uses documented dzud events identified as natural disasters at the national level (Fernandez-Gimenez et al. 2012).

Study sites with meteorological stations include Choibalsan (N 48.067, E 114.5; elevation $756 \mathrm{~m}$ ) in the eastern Mongolian steppe grasslands with a cold, semi-arid climate; Dalanzadgad (N 43.583, E 104.417; elevation $1470 \mathrm{~m}$ ) in the arid desert-steppe of southcentral Mongolia; Hovd (N 48.017, E 91.650; elevation $1406 \mathrm{~m}$ ), a dry steppe zone near the Altai Mountains in the west; and Ulaan Baatar (N 47.933, E 106.983; elevation 1316) in central-northern Mongolia at the edge of the steppe-mixed forest eco-zone (Fig. 1). Ulaan Baatar is the national capital; the other sites are provincial capitals. Using climatological data from Mongolia's National Agency for Meteorology, Hydrology and Environment Monitoring (NAMHEM) and NOAA (National Oceanic and Atmospheric Administration) and UK's Climate Research Unit (Harris et al. 2014), drought was calculated with the Standard Precipitation Index. Findings were then correlated with documented dzud events (see Table 4). The objective was to stress connections between:

1. dzud events preceded by drought

2. drought events followed by dzud

This was done by identifying summer drought events at each site that preceded winter from 1970 to 2015. To do this, drought during the maximum 6-month spring-summer plant growth season was examined at the sites. This captures reduced and negative precipitation anomalies from annualised precipitation records for the April-September potential vegetation growth period in the country. We note that in Mongolian the word 'gan' is translated as drought yet may also signify high temperatures that affect livestock. Results quantify moisture deficiencies which may then contribute to dzud events in the following winter. Data were then analysed to determine association between hazards; the outcome is a record of drought-dzud interaction. This addresses the link between the two hazards with significance for disaster policy, planning and mitigation in Mongolia. Detailed evaluation at

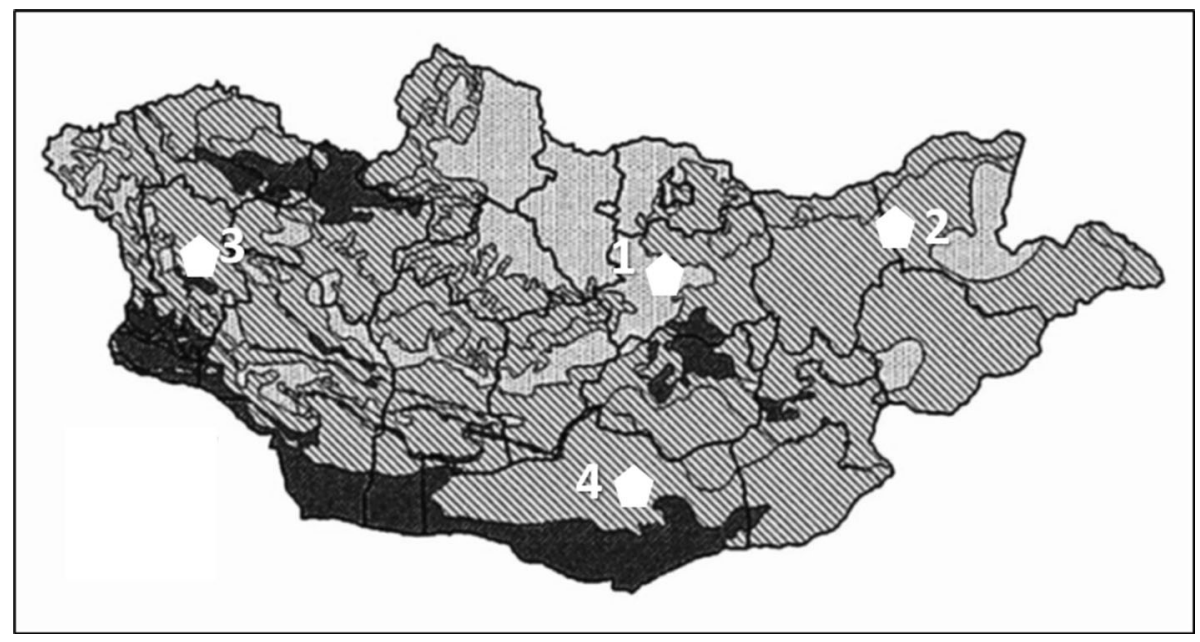

Fig. 12016 pasture vulnerability map indicating dzud hotspots-darker colour indicates greater risk. Meteorological stations: 1 Ulaan Baatar; 2 Choibalsan; 3 Hovd; 4 Dalanzadgad. Source Mongolian Livestock Early Warning System (2016) 
province or district levels, or with other specific dzud criteria (socio-economic factors, livestock mortality; see Table 1) may lead to varied results.

\subsection{Standardised precipitation index}

The standardised precipitation index (SPI) documents anomalous and extreme precipitation and drought events (McKee et al. 1993; Sonmez et al. 2005; Sternberg et al. 2009). Using $>30$ years meteorological data, the SPI gives a numeric value to precipitation surplus or deficiency; this enables drought monitoring at different time scales and facilitates comparison across regions and varied climatic zones. The index calculates drought initiation, magnitude, duration, and frequency; results can be interpolated to provide spatial and temporal drought parameters. The SPI is determined by fitting data to a probability distribution defining a series of aggregated monthly precipitation observations. The cumulative probability of a precipitation amount is calculated with the inverse normal function applied to the probability (Guttman 1999). This enables analytical comparison of exceedance probabilities and comparison of locations at selected timescales $(1,3,6 \ldots$ months). The resulting function gives the cumulative probability for precipitation at a specific station for a given month and timescale; drought intensity reflects the negative precipitation anomaly (McKee et al. 1993; Sternberg et al. 2011). The SPI provides statistical consistency, identification of short and long-term drought episodes and robustness in comparison with other drought indices (Keyantash and Dracup 2002). Additional methodological details are presented in cited work.

Using meteorological data from NAMHEM, NOAA and the UK's Climate Research Unit (Harris et al. 2014) 6-month drought was assessed from 1970 to 2015. The peak biomass and plant growth period, from the 1st of April through the 30th of September, was assessed. The SPI identifies positive/negative anomalies from zero that give a probability indication of event severity; a result of -1 reflects moderate drought, -1.5 severe drought and $<-2$ extreme conditions. With event probability based on a 100 year scale, an extreme drought would be expected to occur 2.3 times per century (Sonmez et al. 2005). As the data record in this study is 45 years, drought frequency is extrapolated rather than a reflection of long-term (unavailable) data.

\section{Results}

Historical drought at Choibalsan, Dalanzadgad, Hovd and Ulaan Baatar Mongolia documents variable moisture levels, fluctuating precipitation patterns over time and disparate drought events across the sites during the 6-month summer plant growth season (Fig. 2ad). In general, the 1980s were part of a wetter phase, whilst the 2000 s were a drier period. Severe and extreme droughts varied across time and sites with drought episodes concentrated in the 2000s. The percentage of assessed months in drought conditions, at 10-14\%, was lower than SPI probability (15.9\%) When related to dzud, data finds limited association between the two hazards. One extreme drought event was correlated with dzud over 45 years; the link between drought and dzud-at a rate $9 \%$, suggests a random connection. The clear finding is that the two events occur independently at multiple sites in Mongolia.

Given established perceptions in the country, matching the drought history and dzud record presents remarkable findings. Since 1970, 3 of 32 dzud events were preceded by drought (Table 5). Thus the two hazards were seldom connected in this sample of high-risk 

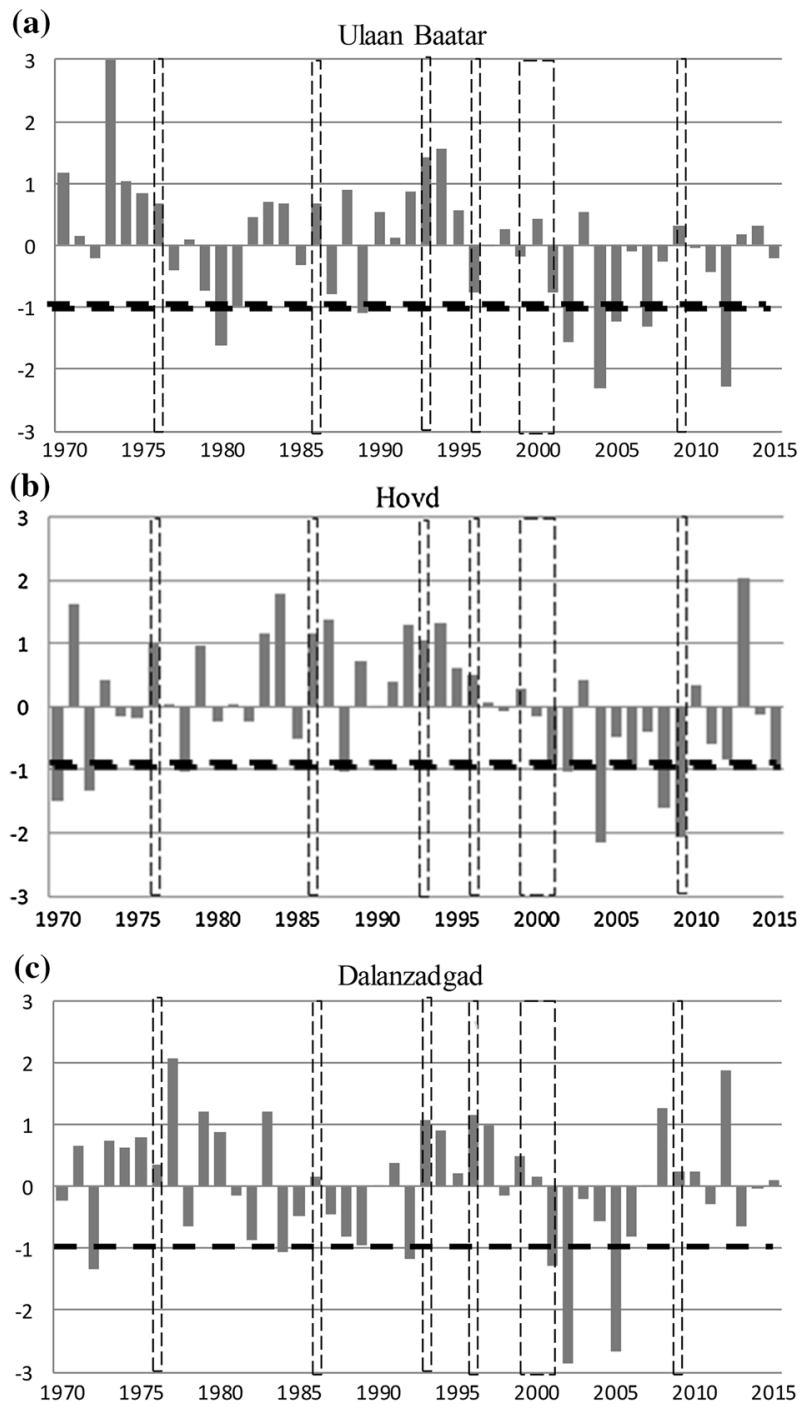

(d) Choibalsan

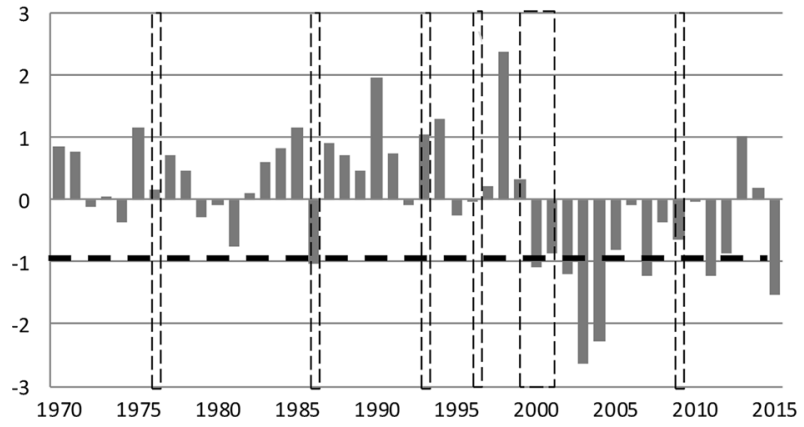


Fig. 2 a-d Drought records for study sites from 1970 to 2015; a Ulaan Baatar, b Hovd, c Dalanzadgad, d Choibalsan. Levels of -1 reflects moderate drought, -1.5 severe drought and $<-2$ extreme events. Boxes (dashed lines) denote dzud years; below the dotted line at -1 indicates the drought threshold

Table 5 Dzud events across sites that were preceded by an identified drought

\begin{tabular}{|c|c|c|c|c|c|}
\hline \multirow[t]{2}{*}{ Year } & \multirow[t]{2}{*}{ Disaster } & \multicolumn{4}{|c|}{ Dzud preceded by drought } \\
\hline & & Dalanzadgad & Hovd & Ulaan Bataar & Choibalsan \\
\hline 1976-1977 & Dzud & - & - & - & - \\
\hline 1986-1987 & Dzud & - & - & - & Yes \\
\hline 1993-1994 & Dzud & - & - & - & - \\
\hline 1996-1997 & Dzud & - & - & - & - \\
\hline 1999-2000 & Dzud & - & - & - & - \\
\hline 2000-2001 & Dzud & - & - & - & Yes \\
\hline 2001-2002 & Dzud & Yes & - & - & - \\
\hline $2009-2010$ & Dzud & - & Yes & - & - \\
\hline
\end{tabular}

winter hazard regions. Examining quantified drought identified 18 events from moderate to extreme severity at the selected timescale. Performing the reverse analysis-droughts followed by dzud-shows that 1 of 11 severe or extreme droughts were linked to dzud whilst 3 of 7 moderate droughts were followed by dzud (Table 6). The extreme droughts in Dalanzadgad $(2002,2005)$ were at 1-in-100 year levels yet were not associated with dzud. Investigation found little relation or causality between drought and dzud in Mongolia over 45 years. Data highlight a random connection between dzud and drought rather than establishing a causal link.

Drought events themselves were seldom related between sites. Only Ulaan Baatar and Choibalsan showed a correlation regarding when precipitation deficits occurred $(P=0.005)$. Other site combinations varied in drought episodes over 45 years. This stresses how Mongolia's environment cannot be characterised by country-wide events. Thus, linkages between drought and other events or inferences need to be identified at more local scales. Analysis points out the inability to draw conclusions on physical parameters at a national scale.

Absence of a notable physical connection between these two natural hazards calls into question how climate variability and hazards interact in the steppe environment. Regional climate dynamics suggest that summer meteorological conditions (such as drought) are decoupled from winter temperature and precipitation events. Findings also highlight how disaster events are presumed and perceived by society. The abundant literature on drought and dzud suggest a strong appeal and intent to connect vegetation productivity, as affected by drought, and exposure to severe winter episodes, factors not evident in this study. Table 7 documents that the majority of dzuds (63\%) were preceded by wetter-than-average climatological conditions.

In winter, reflected in average January temperatures, there was interannual fluctuation but slight variation over the study time (Fig. 3). Temperature was independent of disaster cycles, not having an apparent effect on drought or dzud events. Sites, excepting Ulaan Baatar, showed notable oscillation in average temperature with Hovd having most divergent temperatures. Summer temperatures, measured in July, vary yet show gradual increasing trends over 45 years. Dzud years did not experience the coldest temperatures 
Table 6 Droughts across sites that were followed by dzuds. Table is ranked from most extreme $(-2.86)$ to moderate $(-1.02)$ events

\begin{tabular}{llll}
\hline $\begin{array}{l}\text { Drought } \\
\text { level }\end{array}$ & Year & Location & $\begin{array}{l}\text { Followed } \\
\text { by dzud }\end{array}$ \\
\hline-2.86 & 2002 & Dalanzadgad & No \\
-2.66 & 2005 & Dalanzadgad & No \\
-2.65 & 2003 & Choibalsan & No \\
-2.31 & 2004 & Ulaan Bataar & No \\
-2.27 & 2004 & Choibalsan & No \\
-2.27 & 2012 & Ulaan Bataar & No \\
-2.16 & 2004 & Hovd & No \\
-2.07 & 2009 & Hovd & Yes \\
-1.63 & 1980 & Ulaan Bataar & No \\
-1.60 & 2008 & Hovd & No \\
-1.55 & 2002 & Ulaan Bataar & No \\
-1.48 & 1970 & Hovd & No \\
-1.28 & 2001 & Dalanzadgad & Yes \\
-1.22 & 2005 & Ulaan Bataar & No \\
-1.20 & 2002 & Choibalsan & No \\
-1.08 & 2000 & Choibalsan & Yes \\
-1.02 & 2002 & Hovd & No \\
-1.02 & 1986 & Choibalsan & Yes \\
& & &
\end{tabular}

Table 7 Wetter-than-average (+) versus drier-than-average (-) 6-month SPI episodes preceding dzud events

\begin{tabular}{llllll}
\hline Year & Disaster & Dalanzadgad & Hovd & Ulaan Bataar & Choibalsan \\
\hline $1976-1977$ & Dzud & + & + & + & + \\
$1986-1987$ & Dzud & + & + & + & + \\
$1993-1994$ & Dzud & + & + & + & + \\
$1996-1997$ & Dzud & + & + & - & + \\
$1999-2000$ & Dzud & + & - & - & + \\
$2000-2001$ & Dzud & + & - & + & - \\
$2001-2002$ & Dzud & - & - & - & - \\
$2009-2010$ & Dzud & - & - & + & - \\
\hline
\end{tabular}

just as drought episodes were not marked by intense heat. Rather, there were not clear associations between temperature and hazards. More intra-site difference was found in winter, whilst there was less range in summer.

\section{Discussion}

The findings of this study - that in just 3 of 32 events analysed was dzud preceded by drought - contravene entrenched opinion, bedrock policy foundations, international agency presumptions and development practices. Questioning the drought-dzud assumption and contesting the environment-driven disaster scenario can invigorate research, policy and 

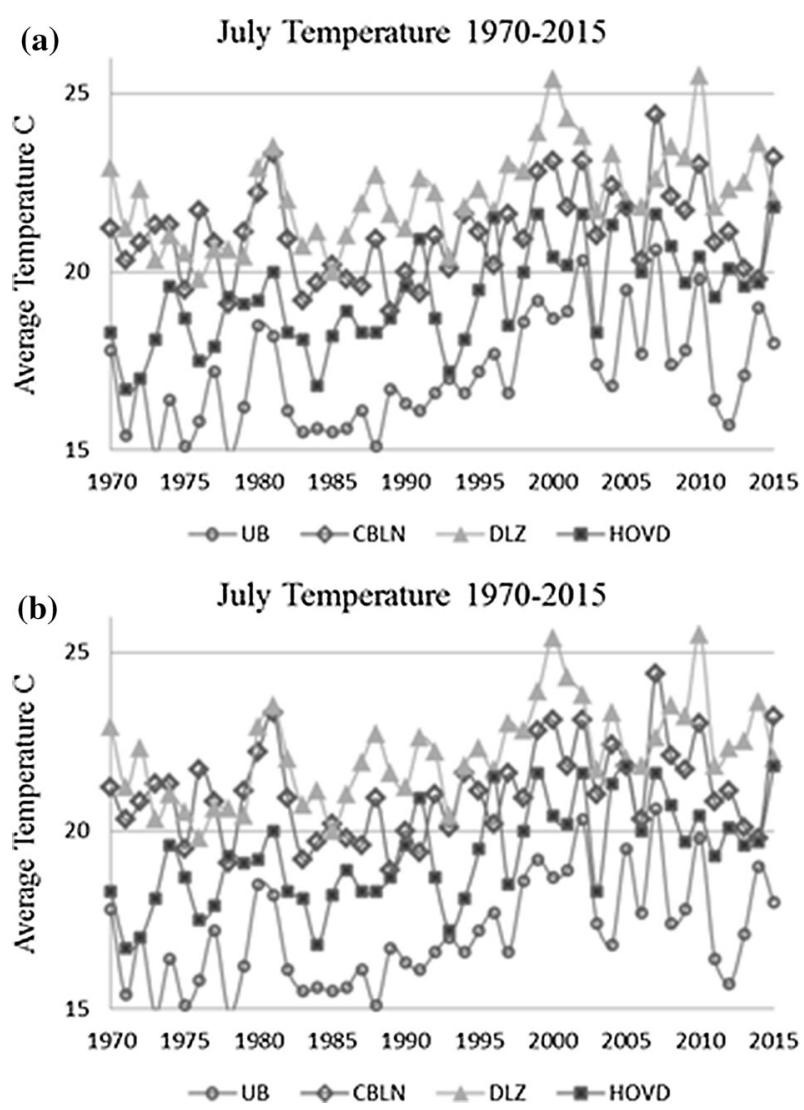

Fig. 3 July and January average monthly temperatures at the sites. January data showed low $r^{2}$ values. An increase in July temperatures reflected a gradual warming trend, Ulaan Baatar $-r^{2}=0.28$; Choibalsan$r^{2}=0.11$, Dalanzadgad $-r^{2}=0.28$, Hovd $-r^{2}=0.41$

disaster mitigation. The ability to better understand hazards has increased significantly over time yet the Mongolian process reflects how the 'drought leads to dzud' inference became an unchallenged link. A new paradigm better suited to on-the-ground realities may do more to reduce disaster impact that increased funding based on past attitudes. Long-standing folk wisdom has an important place in thought and discussion, but it should not limit scientific insight that can ameliorate livelihoods. That other research has not chosen to isolate drought is perhaps not surprising given the predominance that the drought-dzud hypothesis has enjoyed. The study objective was to investigate standard assumptions; results encourage reassessment of physical relationships in Mongolia and the greater region.

The clear outcome of the study is that past and present presumption of drought causality of dzud requires re-examination. Findings suggest more varied and nuanced research that addresses non-drought factors that contribute to dzud is essential (Sternberg 2010; Fernandez-Gimenez et al. 2012). This can commence with further investigation of winter snow depth, timing of freeze-thaw cycles, separating summer and winter climate patterns, anomalous events and early and late-onset disaster. Factors contributing to animal weight gain, mobility, pasture degradation livestock mortality, could be reviewed. Examining disparities between dzud intensity, livestock health and pasture conditions at regional and 
local levels will further understanding. Greater recognition of the role of herder decisionmaking and actions, acknowledgement of their unique ecological insight, the contributory socio-economic forces and government policy is vital. Choices, selection and behaviour have antecedent motivation and commonly, rational reasons if regarded from the herder perspective. Dzud relief efforts, emergency fodder at local and national levels and international aid are part of the context. The extant literature identifies the conflicted, dual nature of dzud and implicitly asks the question 'is it a physical or social disaster?' (Murphy 2012). The body of literature can advance, delve into the bifurcated nature of cold disaster in livestock systems and move beyond the concept that 'drought causes dzud' which has been a poor explanation of complex physio-social processes. Mongolian and international research in the country has progressed greatly in the last 20 years; it remains a puzzle why as technical capacity has improved more effort has not been spent establishing baseline knowledge about endemic hazards. Thus 17 years after the first severe post-soviet era dzud, we continue to rely on Batjargal (1997) and Natsagdorj and Dulamsuren (2001) early assessments of dzud and environmental conditions.

In part reliance on the imprecise drought-dzud relation was born of exigency in the 1990s as Mongolia abruptly moved from communism to a market system through much turmoil. At the same time, advising international agencies had little knowledge of Mongolian natural and social systems. Limited capacity and funding, severe dzuds from 1999 to 2002 and great human misery meant basic response and rapid reaction was needed. With time the concepts of the era became entrenched; now science can reassess the country's hazards and to further engage and test the rather messy intricacies of dzud. We see this in new approaches by Shinoda (2017), Middleton et al. (2015) and Ahearn (2016); now more than previously the research agenda should be wide open from macro- to microscales.

The government role is highlighted through reports written in Ulaan Baatar (e.g. MARCC 2009; National Action Programme on Climate Change 2011; annual National Statistical Yearbook) yet the state maintains a modest presence in the drought and dzud impacted countryside dynamics (Sternberg and Batbuyan 2013). The key perspective is that as government interaction with herding changed from communism's top-down state control to today's laissez faire approach, the assumption of responsibility also changed. Thus, the effective district hay barns of the Soviet era are now empty and derelict; today the disaster response scenario is remote, cumbersome and of limited value to herders. For example, a herder experiencing dzud in Hovd Province, 1800 kilometres from the capital, has little prospect of fodder, relief or aid from the government as exemplified in 2010 (Middleton et al. 2015). Previously response mitigated disaster to a degree; now Mongolia depends on a fickle international community that promises aid but seldom delivers in full (World Bank/Benson C 2011). What does arrive faces severe infrastructure and distribution problems so as to be of little timely, immediate relief. The gradual change in the government's disaster perception, role and performance promotes a drought-dzud focus where the message is of unforeseen, uncontrollable natural hazards beyond the government's remit to address or ameliorate. An updated assessment can directly address the government's limited ability to reduce disaster threat. To herders, it may be preferable to have matters presented clearly rather than foster unreasonable hope of support. This also encourages herders to acknowledge that they are effectively responsible for mitigation.

Data from the Mongolian Statistical Office (2016) provide a way to stimulate new questions at relevant scales. Figures 4 and 5 present changes in livestock numbers at the national level and in the four selected provinces. Patterns show much annual variability with decreases after major dzud events. Examining livestock numbers and hand-collected fodder harvests (reflecting herder effort) show the strong drivers that can affect extreme 


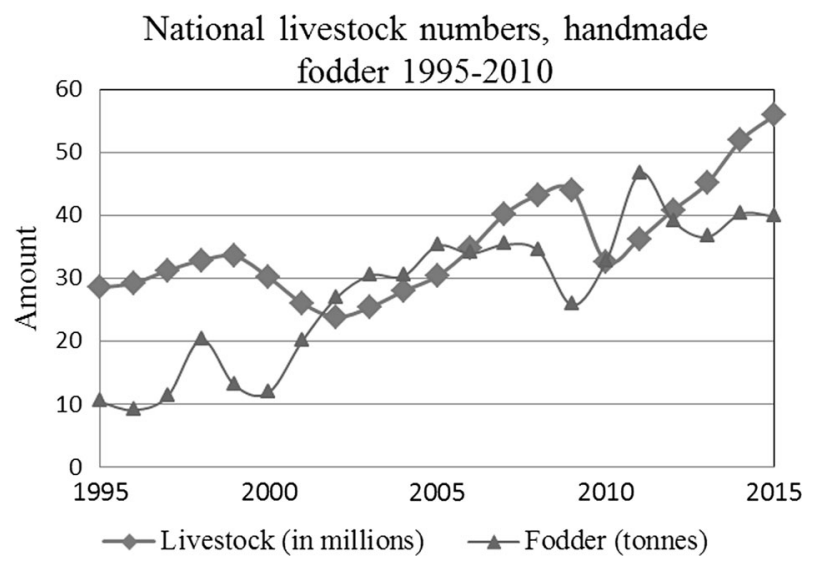

Fig. 4 Livestock numbers in the four study provinces, 1990-2015. This examines change in animals, not livestock mortality. National Statistical Office 2016

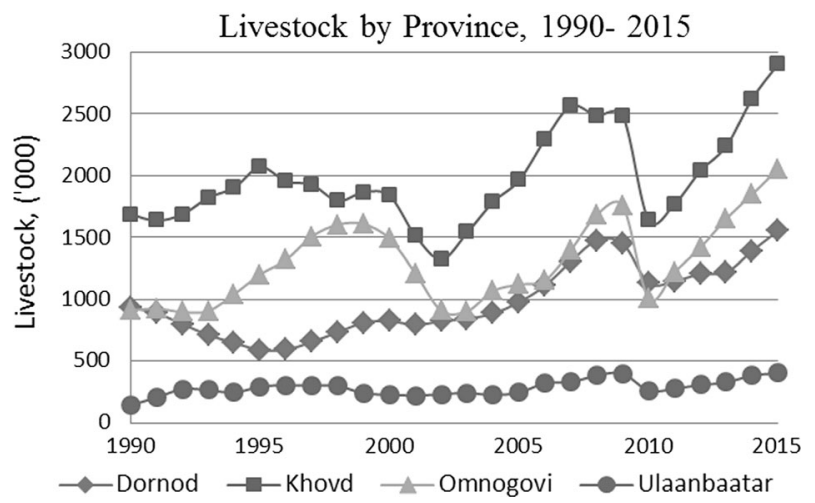

Fig. 5 Two trends affecting disaster vulnerability that reflect human influence in natural disaster. The first presents herder collection of fodder by hand for emergency winter supply. In the second, livestock numbers show a doubling of animals in less than 15 years. National Statistical Office 2016

events (Fig. 5). One is positive-the collection of fodder by hand for emergency winter supply $\left(r^{2}=0.8\right)$ whilst a doubling of livestock in less than 15 years increased pressure on pastoral systems. The livestock curve is impressive as animal numbers increased from 22 million in post-dzud 2002 to 51 million in $2014\left(r^{2}=0.6\right)$ with similar patterns of livestock change in the four study sites (Fig. 5). Over the same time the amount of fodder has distinctly fluctuated. The 1990s were low-harvest years. After the 1999-2002 dzud era fodder collection increased, only to decline through 2009 as drought but not dzud occurred. Drought affects the amount of vegetation cover and plant biomass, thus potentially limiting forage for animal weight gain and reducing fodder harvests. Following the 2009-2010, dzud fodder harvest increased $26 \%$ in the immediate year and $42 \%$ the next, to then drop $15 \%$. The national and provincial data provides a lens to conceive of the wide range of potential human factors affecting pastoral vulnerability. The motivations reflect both economic-increase herd size for revenue and practical reasons-improve veterinary nutrition and provide fodder to keep animals from starving. Throughout processes 
decision-making, key players (herder households, government, NGOs) and their actions are divergent yet impacted by natural hazards.

Increasing livestock numbers, variable fodder resources, intermittent drought events and less-remarked yet significant allied practices (e.g. mobility, animal intensification, markets, competition for water) raise additional concerns that are reflected in research literature. This centres on physical resources, degradation, overgrazing, land tenure etc. and their implications for herding practices, assigning vulnerability and criticising herders when rational livelihood decisions (increased livestock) may be regarded as negative processes environmentally. This apparent conundrum, a version of Hobson's choice-selecting environmental vs economic benefit — can potentially be a sustainable option depending on context and resources. Additional livestock may be feasible (and not detrimental) if they are accompanied by adequate pasture, mobility, fodder, lack of resource competitionfactors that enable increased levels of productivity. The disaggregation of multiple factors is difficult in the strictures of an academic article, yet this paper raises the point that pastoralism has several approaches as different as the herders practicing it. Their inherent local wisdom and ecological knowledge may be more reliable than desk-based drought or dzud analysis (this paper included). Yet to influence policy, practice, funding and mitigation at national or international scales data, justification and explanation is required. This article challenges one of the established pastoral axioms in questioning the relationship between drought and dzud.

The study data present four meteorological stations over a 45-year period. The country's large size and disparate landscapes encourages more in-depth study both at the national level and within regions and localities. One challenge is the limited number of stations in the country. NOAA identifies 40 stations nationwide, or one station per $39,000 \mathrm{~km}^{2}$ (compare this to nearby Kazakhstan, with one station for every $8200 \mathrm{~km}^{2}$ or Iceland, one per $1470 \mathrm{~km}^{2}$ ). This means much detail is lost due to scale issues and recognises that results may differ in a detailed province or district level study. A potential new method would be to use extracted global data sets, such as from the UK's Climate Research Unit at the University of East Anglia that generates gridded data sets from 1900 (Harris et al. 2014). The caveat is that for much of the period Mongolia had limited weather monitoring, thus extrapolated data would lack accuracy and value for much of the twentieth century. Other technical approaches, such as satellite vegetation, temperature or moisture monitoring, can provide a short-term perspective on climate and pasture fluctuation in the country. The UNESCO Remote Sensing Lab at Mongolian National University and the National Remote Sensing Office are two capable centres that could engage in remotely sensed environmental monitoring, whilst NAMHEM can undertake climate monitoring.

An interesting factor is that dzud is a particularly Mongolian phenomenon, at least in its perception as a major disaster. The word dzud is Mongolian; across the border in northern China there is no local equivalent. The closest term is 'snow disaster' that lacks the impact or urgency of dzud. Equally, there is little research on dzud in Kazakhstan, perhaps in part due to the decrease in pastoralism and sedentarisation of recent decades. Both countries share the steppe landscape and herding traditions yet do not perceive or experience major dzuds nor focus on a drought-dzud link. This suggests the dynamics are country-specific and that the disasters reflect unique domestic factors. These may include the importance of pastoralism as a livelihood in Mongolia, the high proportion of rural residents, limited nonherding opportunities in the countryside and strong cultural links to pastoralism. Climate threats may also highlight the decline in effectiveness of the government to mitigate hazards over recent decades, or the concurrent dramatic growth in livestock numbers that increases pasture stress and herder vulnerability. These key factors reflect social influences 
rather than physical parameters. The principal message becomes that disaster is significant in the country, that they are multifaceted and result from physical forces and human action. 'Drought causes dzud' becomes an ingenuous assumption that was not supported by investigation-in 29 of 32 events analysed, dzud was not preceded by drought. Clarity on causal complexity will strengthen disaster strategies with significant benefit for pastoralists at the centre of the hazard tempest.

\section{Summary}

Whilst natural disasters are endemic in Mongolia, a clear understanding of hazard links and contributory factors has been elusive. The country's chaotic transition away from communism led to a generation of social and development processes and thought that excused society from looking too closely at hazard causality. Through times of uncertainty Mongolians' approach to hazards has been settled in logic, presumption and the status quo. Yet it serves poorly if on-the-ground reality diverges from long-held belief. This succinct study of drought and dzud in diverse areas of the country makes this important point as findings identify a lack of causality between the disasters. An event-by-event examination at Choibalsan, Dalanzadgad, Hovd and the capital Ulaan Baatar stresses the independence of dzud and drought. This is case whether evaluating dzud preceded by drought or the inverse, drought followed by dzud.

Findings that drought preceded dzud in just 3 of 32 analysed events suggest more assiduous investigation of disasters is needed in the country. Efforts could focus at larger scales to highlight variegation, then distil details at regional and local levels and by environmental zones. This special journal issue on Eurasia provides a format to intensively examine disasters from different angles. Hazards instigate physical and social processes; in Mongolia their impact reverberates across several research fields as diverse as livestock science, ecology, economics, development, migration and climatology to sociology and governance. Assessment should be encouraged to use contemporary techniques in combination with knowledge generated through intensive study to better serve individuals and communities. Only then will disaster strategies improve their ability to mitigate Mongolia's unusual hazard scenarios.

Acknowledgements Research was supported by the John Fell Fund, University of Oxford, Mongolia's National University and Academy of Sciences and China's International Science and Technology Cooperation Program of China (No. 2013DFA91700). Discussion at the 3rd Oxford Desert Conference (UK) and the University of Nagoya's 4D-'Multi-Hazard Approach in Mongolia' workshops encouraged conceptual development. Special thanks goes to Masato Shinoda, Ariell Ahearn and Batbuyan for their insights and conversations.

Open Access This article is distributed under the terms of the Creative Commons Attribution 4.0 International License (http://creativecommons.org/licenses/by/4.0/), which permits unrestricted use, distribution, and reproduction in any medium, provided you give appropriate credit to the original author(s) and the source, provide a link to the Creative Commons license, and indicate if changes were made.

\section{References}

Ahearn A (2016) The role of kinship in negotiating territorial rights. Inner Asia 18:245-264

Batima P, Natsagdorj L, Gombluudev P, Erdenetsetseg B (2005) Observed climate change in Mongolia. Assess Imp Adapt Clim Change Work Pap 12:1-26 
Batjargal Z (1997) Desertification in Mongolia. RALA Report 200:107-113

Bayarjargal Y, Karnieli A, Bayasgalan M, Khudulmur S, Gandush C, Tucker C (2006) A comparative study of NOAA-AVHRR derived drought indices using change vector analysis. Remote Sens Environ 105:9-22

Below R, Grover-Kopec E, Dilley M (2007) Documenting drought-related disasters a global reassessment. J Environ Dev 16:328-344

Cutter S, Barnes L, Berry M, Burton C, Evans E, Tate E, Webb J (2008) A place-based model for understanding community resilience to natural disasters. Glob Environ Change 18:598-606

FAO (2010) FAO's role in the Mongolia dzud appeal. fao.org/fileadmin/user_upload/emerg encies/docs/ app_mongoliadzud2010.pdf. Accessed 26 Nov 2016

FAO/Suttie J (2006) Country Pasture and Forage Resource Profiles-Mongolia. FAO report

Fernandez-Gimenez M (2000) The role of Mongolian nomadic pastoralists' ecological knowledge in rangeland management. Ecol Appl 10:1318-1326

Fernandez-Gimenez M, Batkhishig B, Batbuyan B (2011) Mongolia - Understanding resilience in Mongolian pastoral social-ecological systems: adapting to disaster before, during and after $2010 \mathrm{dzud}$. World Bank. http://documents.worldbank.org/curated/en/946711468061500091/Mongolia-Understandingresilience-in-Mongolian-pastoral-social-ecological-systems-adapting-to-disaster-before-during-and-after2010-dzud

Fernandez-Gimenez M, Batkhishig B, Batbuyan B (2012) Cross-boundary and cross-level dynamics increase vulnerability to severe winter disasters (dzud) in Mongolia. Glob Environ Change 22:836-851

Government of Mongolia Appeal for International Assistance for Mongolia-Winter Disaster-Dzud (2001) reliefweb.int/report/mongolia/un-and-government-mongolia-appeal-inter national-assistancemongolia-winter-disaster. Accessed 26 Jan 2016

Guttman N (1999) Accepting the standardized precipitation index: a calculation algorithm. J Am Water Resour As 35:311-322

Harris I, Jones Osborn T, Lister D (2014) Updated high-resolution grids of monthly climatic observationsthe CRU TS3. 10 Dataset. Int J Climatol 34:623-642

Hauck M, Dulamsuren C, Heimes C (2008) Effects of insect herbivory on the performance of Larix sibirica in a forest-steppe ecotone. Environ Exp Bot 62:351-356

IFRC (International Federation of the Red Cross) (2016) http://www.ifrc.org/en/news-and-media/pressreleases/asia-pacific/mongolia/red-cross-launches-emergency-appeal-as-extreme-winter-dzud-threatensmongolian-herders-/. Accessed 26 Nov 2016

IPCC (2012) Managing the risks of extreme: vvents and disasters to advance climate change adaptation. In: Field et al. Cambridge Press, Cambridge

Keyantash J, Dracup J (2002) The quantification of drought: an evaluation of drought indices. Bull Am Meteorl Soc 83:1167-1180. doi:10.1175/1520-0477(2002)083

Mayer B (2016) Climate migration and the politics of causal attribution: a case study in Mongolia. Migr Dev 5:234-253

McKee T, Doeskan N, Kleist J (1993) The relationship of drought frequency and duration to time scales. In: Eighth conference on applied climatology, American meteorological association, Anaheim, CA, pp 179-184

Miao L, Fraser R, Sun Z, Sneath D, He B, Cui X (2016) Climate impact on vegetation and animal husbandry on the Mongolian plateau: a comparative analysis. Nat Hazards 80(2):727-739

Middleton N, Rueff H, Sternberg T, Batbuyan B, Thomas D (2015) Explaining spatial variations in climate hazard impacts in western Mongolia. Landsc Ecol 30:91-107

Mongolian Livestock Early Warning System (2016) Forage Deviation www.mongolia lews.net/index.php/ map-products/english/. Accessed 22 Feb 2016

Murphy DJ (2011) Going on otor: disaster, mobility, and the political ecology of vulnerability in Uguumur Mongolia. PhD thesis, University of Kentucky

Murphy DJ (2012) Encountering the franchise state: dzud, otor, and transformations in pastoral risk. In: Knauft BM, Taupier R (eds) Mongolians after socialism. Admon Press, Ulaanbaatar, pp 68-80

Nandintsetseg B, Shinoda M (2013) Assessment of drought frequency, duration, and severity and its impact on pasture production in Mongolia. Nat Hazards 66:995-1008

National Statistics Office/Mongolian Statistical Yearbook www.en.nso.mn. Accessed 06 Dec 2016

Natsagdorj L, Dulamsuren J (2001) Some aspects of assessment of the dzud phenomena. Pap Meteorol Hydrol 23:3-18

New York Times (2016) Mongolia's Livestock in danger after drought, harsh winter 2016/02/26 http:// www.nytimes.com/aponline/2016/02/26/world/asia/ap-as-mongolia-harsh-winter.html?_r=0. Accessed 28 Jan 2016 
Pederson N, Hessl A, Baatarbileg N, Anchukaitis K, Di Cosmo N (2014) Pluvials, droughts, the Mongol Empire, and modern Mongolia. Proc Natl Acad Sci 111:4375-4379

Rajsekhar D, Singh V, Mishra A (2015) Multivariate drought index: an information theory based approach for integrated drought assessment. J Hydrol 526:164-182

Rao M, Davi N, D’Arrigo R, Skees J, Nachin B, Leland C, Lyon B, Wang S, Byambasuren O (2015) Dzuds, droughts, and livestock mortality in Mongolia. Environ Res Lett 10:074012

Shinoda M (2012) Proactive Management of Drought and Its Derived Disasters in Mongolia. In: Tran P, Shaw R (eds) Environment disaster linkages. Emerald Group Publishing, Bingley, pp 61-78

Shinoda M (2017) Evolving a multi-hazard focused approach for arid Eurasia. In: Sternberg T (ed) Climate hazard crises in Asia. Routledge Publishers, Abingdon

Sonmez K, Komuscu A, Erkhan A, Turgu E (2005) An analysis of spatial and temporal dimension of drought vulnerability in Turkey using the standard precipitation index. Nat Hazards 35:243-264. doi:10.1007/s11069-004-5704-7

Sternberg T (2010) Unravelling Mongolia's extreme winter disaster of 2010. Nomadic Peoples 14:72-86

Sternberg T, Batbuyan B (2013) Integrating the Hyogo Framework into Mongolia's disaster (DRR) policy. Int J Disaster Risk Reduct. doi:10.1016/j.ijdrr.2013.05.003

Sternberg T, Thomas D, Middleton N (2009) Pressurized pastoralism in South Gobi Province, Mongolia: what is the role of drought? Trans Br Geogr IBG 34:364-377

Sternberg T, Thomas D, Middleton N (2011) Drought dynamics on the Mongolian steppe, 1970-2006. Int J Climatol 31:1823-1830

Tachiiri K, Shinoda M, Klinkenberg B, Morinaga Y (2008) Assessing Mongolian snow disaster risk using livestock and satellite data. J Arid Environ 72:2251-2263

UNDP/NEMA (2010) Dzud national report 2009-2010. UNDP-NEMA, Ulaanbaatar

United Nations (2016) Mongolia: dzud. United Nations Office of the Resident Coordinator. www.unmongolia.mn

UNOCHA (2010) Mongolia dzud appeal unocha.org/cap/appeals/mongolia-dzud-appeal-2010. Accessed 26 Nov 2016

World Bank (2010) http://blogs.worldbank.org/eastasiapacific/dzud-a-slow-natural-disaster-kills-livestockand-livelihoods-in-mongolia. Accessed 10 Dec 2010

World Bank (2011) Exploring options to institutionalize the dzud disaster response product in Mongolia. No. 12760. World Bank, Washington

World Bank/Benson C (2011) Dzud disaster financing and response in Mongolia. World Bank, Washington 